\title{
CABOCLOS EM MOVIMENTOS: DANÇAS DE CABOCLOS NO CANDOMBLÉ EM SALVADOR ${ }^{1}$
}

\author{
Ana Rizek Sheldon ${ }^{2}$
}

\begin{abstract}
Resumo: Este artigo aborda os caboclos através de sua dança em terreiros de candomblé de Salvador. Partindo do conceito latouriano de articulação, mostra as celebraçóes como momentos de adensamento de dinâmicas relacionais que favorecem articulaçóes entre entidades e pessoas. Primeiro, o trabalho discute como a presença das entidades se revela aos filhos de santo enquanto possibilidade de movimento e ganha novos contornos a medida em que o corpo é "articulado" por diversos elementos do terreiro como a música, a composição do espaço e outros corpos em movimento. Depois, aborda como o modo dos caboclos se moverem está relacionado às articulaçóes que eles promovem e de que são parte. Por fim, o texto procura salientar que o jeito de cada caboclo se portar e sambar está implicado nas relações estabelecidas por ele, que podem extrapolar os momentos de festa, redirecionar conexóes pregressas e atravessar geraçóes.
\end{abstract}

Palavras-chave: Caboclo; Candomblé; Dança.

CABOCLOS IN MOVEMENT: THE DANCE OF CABOCLOS IN THE CANDOMBLÉ OF SALVADOR, BAHIA

\begin{abstract}
The paper approaches the caboclos, spiritual entities found in brazilians Afro-indigenous religions, through their dance in Candomblé temples in Salvador de Bahia. Resorting to the Latour's concept of articulation, it describes public celebrations as moments that thicken the terreiro's relational dynamics and favor articulations between entities and humans. It discusses how the presence of caboclos reveals itself to candomblé novices as a possibility of movement whose contours change as the novices' bodies are articulated in the terreiro by elements

\footnotetext{
${ }^{1}$ Como citar: SHELDON, Ana Rizek. Caboclos em movimentos: danças de caboclos no candomblé em Salvador. Debates do NER, Porto Alegre, v. 2, n. 38, p. 243 - 279, 2020.

${ }^{2}$ Doutoranda no Programa de Pós-Graduação em Ciências Sociais da Universidade Federal da Bahia, Brasil. E-mail: queridasputnik@gmail.com.
}

Debates do NER, Porto Alegre, Ano 20, N. 38, P. 243-279, AGo./DeZ. 2020 
such as music, and other moving bodies. It then argues that the way the caboclos move is closely related to the articulations which they promote and in which they participate. Finally, it concludes that the way each caboclo behaves and dances is implicated in the relations he establishes with others, relations that can go beyond the duration of the ritual, redirect previous connections and cut across generations.

Keywords: Caboclo; Candomblé; Dance.

\section{INTRODUÇÃO}

Caboclos são entidades brasileiras que habitam este território desde antes do estabelecimento das entidades africanas por aqui. São descritos como ancestrais indígenas e são agrupados de acordo com linhas e funçóes como: caboclos de pena (ditos índios brasileiros); caboclos de couro (boiadeiros, vaqueiros e capangueiros); caboclos das águas (marujos, pescadores e sereias). Muitas vezes, suas histórias contam como viveram, morreram e como depois de falecidos se tornaram caboclos ou encantados zelando por quem lhes dedica devoção.

Este texto trata da dança dos caboclos no candomblé. Tem o objetivo de discutir como as relaçôes tecidas pelos caboclos compóem o seu modo de se mover. $\mathrm{O}$ trabalho é resultado de pesquisa de doutorado em andamento, realizada por aproximadamente dois anos em alguns terreiros de candomblé em Salvador, Bahia. Nesse período, acompanhei, como visitante, festas públicas dedicadas aos caboclos e conversei com muitas pessoas - mãe, pais e filhos de santo - em cujos corpos essas entidades chegam. As descrições e

${ }^{3}$ Candomblé é uma variante das religiôes de matriz africana que se organizaram como as conhecemos atualmente por volta do século XIX no Brasil a partir de saberes, cosmovisóes e práticas trazidos por africanos escravizados em trânsito para cá ao longo de três séculos. Seus saberes e práticas foram reconfigurados em processos de interação cultural com o catolicismo ibérico, as culturas ameríndias e o espiritismo kardecista (Parés, 2018, p. 377).

Debates do NER, Porto Alegre, ANo 20, N. 38, P. 243-279, Ago./Dez. 2020 
narrativas apresentadas no artigo são fruto de trabalho de campo realizado, parcialmente, em três terreiros de Salvador, localizados nos bairros Liberdade, Sete de Abril e Pau da Lima. As casas são bastante distintas entre si no que diz respeito ao tamanho, número de adeptos e tempo de inauguração, embora essas informações façam diferença na caracterização dos terreiros e de suas dinâmicas, são as entidades caboclas e seus movimentos que ocupam a centralidade deste artigo.

Caboclos são entidades presentes numa vasta gama de religióes de matriz africana no Brasil. No candomblé baiano convivem com divindades africanas - orixás, inquíces ou voduns. Como os orixás, eles baixam nos corpos de alguns adeptos (chamados rodantes ${ }^{4}$ ) e dançam em cerimônias abertas ao público. As danças das entidades são compostas por repertórios de gestos e passos, partilhados coletivamente, aprendidos ao longo do tempo pela observaçáo e pelo envolvimento dos adeptos nas casas que os abrigam. Esses repertórios apresentam variações de acordo com as naçóes ${ }^{5}$, mas também variam entre as famílias de santo e entre os terreiros. Cada entidade tem seu próprio repertório de gestos. Dentre esse repertório geral, podem ser identificadas pequenas diferenças no modo como as entidades particulares se movem, a começar pelo jeito como cada uma delas altera a postura do adepto ao se fazer presente.

A chegada de uma entidade se mostra como uma mudança na disposição corporal de quem a recebe e acarreta uma mudança qualitativa no corpo do rodante. De acordo com Anjos (2006, p. 21), trata-se de um momento crítico em que uma diferença é carregada para dentro do sujeito que, por sua vez, tem que aprender a ceder o corpo e a consciência para a ação de uma entidade que não coincide mais totalmente com ele. Esse momento

${ }^{4}$ Rodante é a designação dos religiosos que recebem orixás e demais entidades em seus corpos, que "rodam com santo". Ser rodante não é algo que depende de uma escolha individual, é uma condição que pode se estabelecer antes do processo de iniciação.

${ }^{5}$ Em Salvador, as nações de candomblé mais conhecidas por suas tradições são Angola, Ketu e Jêje. 
crítico, marcado pela alteraçáo do prumo do corpo, é enfatizado por dois termos êmicos que descrevem o processo dessa alteração se estabelecer, deflagrando a chegada e permanência momentânea da entidade, são eles o barravento e o tombo.

Quando uma entidade chega, diz-se que a pessoa tomou um barravento. $\mathrm{O}$ barravento designa ao mesmo tempo um ritmo de toque dos atabaques e o processo de chegada de uma entidade. É a aproximação da entidade que altera repentinamente a postura do rodante. Ele indica uma transiçáo muito breve entre o instante em que não é mais apenas a pessoa que se move, mas a entidade ainda náo tomou completamente $a$ frente do movimento no corpo do rodante. Um limiar entre a perda de prumo do rodante enquanto a entidade irrompe em seu corpo e nele se apruma.

Cada orixá, inquíce ou caboclo produz um barravento diferente em consonância com suas características e com as relaçôes estabelecidas com o adepto e com o terreiro. Esses movimentos também podem variar de intensidade ao longo do tempo. De certa forma, o termo coloca em evidência náo apenas o momento em que a presença da entidade se confirma, mas também as condiçôes que propiciaram a instauração dessa presença. $\mathrm{O}$ barravento faz a pessoa tombar. O tombo, por sua vez, é a quebra da postura do rodante, também remete a uma certa habilidade para lidar com o desequilíbrio promovido pela chegada de determinada entidade. Ao mesmo tempo, quando uma pessoa ou entidade demonstra firmeza no jeito de dançar, diz-se que ela tem tombo. Além disso, o tombo está associado ao pertencimento da entidade e do adepto a um terreiro, pois cada casa tem um tombo, ou seja, um estilo, um jeito característico de fazer e concatenar os movimentos.

A primeira expressão destaca a importância do reconhecimento do momento crítico em que o processo de chegada da entidade acontece. A segunda remete a um modo coletivo e compartilhado de acolher a entidade, enfatizando a diferença que ela produz no corpo do rodante através da sua maneira de movimentá-lo. Enquanto o barravento diz respeito a uma mudança mais facilmente notada por visitantes pouco familiarizados com 
as dinâmicas que compõem a vida religiosa no candomblé, o tombo remete a diferenças mais sutis que são mais perceptíveis com a convivência.

Rabelo (2014, p. 129) observa que no candomblé "rodar com santo" é um evento relacional: as entidades são mobilizadas por contextos significativos, com os quais dialogam. Sua vinda pode ser referida como uma resposta - elas chegam em resposta ao toque dos tambores, a procedimentos rituais e situaçôes de circulação intensa de energia no terreiro. De acordo a autora (Rabelo, 2014, p. 155) a presença das entidades que rodam com os filhos de santo é percebida primeiramente como possibilidade cinética e gradativamente adquire uma fisionomia específica como constelação de qualidades cinéticas, na medida em que a relação entre adepto e entidade se fortalece, aumentando também a conexão entre eles e o terreiro.

Esse processo gradativo interfere no modo de se mover dos caboclos. O conceito de articulação apresentado por Latour (2008, p. 43) se faz útil aqui para pensar essa questão. Articulação diz respeito à trajetória dinâmica através da qual cada vez mais diferenças são registradas no mundo, graças à mediação de arranjos artificiais envolvendo elementos como objetos, pessoas, sons e lugares. Ao se tornar alvo de procedimentos rituais e experimentar situaçóes diversas no terreiro, o rodante aprende a se sintonizar com as entidades que tomam seu corpo e passa a habitar o mundo em que essas entidades contam, isto é, fazem diferença. Desse processo de articulação participam seus mais velhos ${ }^{6}$ no terreiro, os toques dos atabaques, as comidas oferecidas às entidades, o arranjo de outros corpos numa roda etc. Assim, articulação refere-se tanto à aquisição de um corpo relacional sensível a camadas cada vez mais sutis de diferenças, quanto ao ingresso e participação em um mundo cada vez mais diferenciado.

Nesse sentido, o corpo no candomblé é feito passo a passo. Para quem aprendeu a ver ${ }^{7}$, ele comporta muitas camadas de diferença. Perceber o

\footnotetext{
${ }^{6}$ Expressão que designa aqueles adeptos que foram iniciados há mais tempo.

${ }^{7}$ Ver a esse respeito o texto de Rabelo (2015) que aborda o aprendizado de práticas visuais no candomblé, seguindo uma abordagem fenomenológica.
}

Debates do NER, Porto Alegre, Ano 20, N. 38, P. 243-279, AGo./DeZ. 2020 
tombo exige uma certa articulação (Latour, 2008, p. 43), ou seja, exige o registro de algo que passa a fazer uma diferença. Só se é capaz de reconhecer se alguém tem tombo, quem consegue notar essa diferença na movimentação. Ao mesmo tempo, quem tem tombo exibe no movimento uma qualidade que pode indicar a posição ocupada (tanto pelo rodante, quanto pela entidade) no terreiro. A proposiçáo de um dos pais de santo entrevistados durante a pesquisa descreve esse processo:

O muzenza é o gingado. Para quebrar mesmo, se o muzenza tiver duro, tiver o pé duro. Esse balanço é para poder amolecer o gingado mesmo e aprender a gingar, escutar o compasso das ngomas ${ }^{9}$ para entrar no ritmo. Eu acho que o pé de dança do iaô, ou do muzenza, começa no roncó ${ }^{10}$. Naquilo ali você já sabe se tem o pé de dança ou não. E encontrar o ritmo, dança é isso, é o ritmo, é o compasso. E quebrar o jincá ${ }^{11}$ para amolecer. Agora existem entidades que são mais desenvolvidas. Acho que é de acordo também com a matéria. Até dizem "ah, porque a matéria sabe dançar e o espírito não sabe". Eu conheço pessoas que sabem dançar e quando o orixá está em terra ele é bem mais maleável, bem mais sereno. E conheço pessoas que não tem o pé de dança, não tem compasso e quando o orixá está em terra ele arrasa. É também uma questâo de se dedicar ao aprendizado, a aprender. Tem gente que não se dedica a aprender e experimentar entrar no ritmo, tudo tem a ver com o compasso (Entrevista concedida em setembro de 2018).

A fala transcrita acima, descreve o processo de aprendizado da dança do iniciado a partir do gingado. É o balanço que quebra o muzenza (o noviço). É preciso fazer o novo filho de santo amolecer o pé, quebrar a dureza do corpo. Embora não comece e nem termine com a iniciação, esse aprendizado ganha destaque durante o período em que o noviço é recolhido. A iniciação

\footnotetext{
${ }^{8}$ Nome dado ao iniciado nas casas de tradição Angola.

${ }^{9}$ Denominação dos atabaques.

${ }^{10}$ Quarto onde acontecem os ritos de iniciação do filho de santo.

${ }^{11}$ A palavra jincá diz respeito a um movimento de ombros, um modo de dançar.
} 
produz diferenças que fazem o noviço adquirir um corpo mais disponível para ouvir o compasso e finalmente entrar no ritmo das ngomas - os atabaques. Embora o caboclo não precise passar por ritos de iniciação ${ }^{12}$ para virar $^{13}$ o rodante, sua postura também pode ser alterada mediante a iniciação, pois a iniciação diferencia o modo como o caboclo pode se relacionar com outras entidades, já que ele passa a integrar uma complexa trama de relaçóes que ligam o adepto ao terreiro. Primordialmente, a iniciação fortalece a relação entre o adepto, o orixá para o qual é feito ${ }^{14}$, a mãe ou pai de santo que o inicia e as entidades que habitam o terreiro. No caso daqueles noviços que já rodavam com caboclo, a iniciação produz um intervalo de um ano no qual as entidades não podem se manifestar. Decorrido esse tempo, os caboclos voltam a comparecer no terreiro e no corpo dos filhos de santo recém feitos. Desse momento em diante, a exigência quanto ao respeito que devem demonstrar à autoridade da mãe ou pai de santo e às divindades africanas se acentua.

A demonstração de reverências aos sacerdotes, aos mais velhos e às entidades que habitam a casa é requerida mais enfaticamente ao adepto após a iniciação. Isso acontece através de gestos que são mobilizados pela presença dessas pessoas e entidades. Em sua realização, os movimentos do iniciado e da entidade são ajustados às maneiras partilhadas por membros da casa de compor essas deferências. Os gestos e movimentos dos caboclos, suas reverências e danças também se tornam alvo de ajuste e afinação de maneira mais formal após esse período. Durante as celebraçôes abertas ao público, a

${ }^{12}$ Em algumas casas, os caboclos são identificados como entidades que não adentram o roncó, ou seja, que não passam pelo recolhimento característico do período de adensamento dos procedimentos que fazem o filho de santo e orixá. Embora orixás e outras entidades possam rodar com o adepto antes da iniciação, essa identificação do caboclo como aquele que não é recolhido marca uma distinção dessas entidades com as demais.

${ }^{13}$ Virar é um dos termos nativos para a chegada da entidade ao corpo do rodante, ele enfatiza o movimento que transforma o corpo do rodante. Sobre isso, ver: Rabelo, 2014, p. 183.

${ }^{14}$ A divindade que é considerada regente da cabeça, que tem uma influência mais forte durante os primeiros anos do iniciado.

Debates do NER, Porto Alegre, ano 20, N. 38, P. 243-279, Ago./Dez. 2020 
habilidade do adepto e das entidades em mostrar certa adequação ao estilo da casa e, ao mesmo tempo, expressar uma maneira singular de se mover é constantemente notada por visitantes que podem tecer comentários sobre o assunto. Nas festas públicas, os vínculos e relaçóes entre os adeptos, assim como entre eles e as entidades, tomam forma na disposição que cada um apresenta ao se mover, bem como nas dinâmicas coletivas que mobilizam os membros do terreiro. Quanto mais assídua for a assistência nas festas do terreiro, mais habilidosos serão os convidados em identificar a implicação das relaçóes nos repertórios de movimento e em como eles são mobilizados, modulando sutilezas de sentido à experiência do público.

A partir do que ocorre no roncó, onde a iniciação acontece, avalia-se se o santo que está sendo feito tem o pé de dança. A expressão "ter o pé de dança" indica um sentido de corpo - nesse caso, de pé - que pode vir a ser adquirido. É uma questáo de se dedicar, aprender e experimentar. Ao mesmo tempo, o pé de dança do orixá não necessariamente coincide com o do adepto, o que marca uma diferença de quem faz o movimento no pé. Maleabilidade é uma qualidade que aparece na fala transcrita acima, como fundamental para fazer o iniciado entrar no ritmo. Entrar no ritmo não diz respeito necessariamente à repetição coordenada do mesmo conjunto de passos ao mesmo tempo. Diz respeito, isso sim, a um engajamento que atravessa todo o corpo para encontrar um modo de fazer parte da composiçáo coletiva; de dar passagem ao movimento para fazer reverberar um ritmo no corpo. No processo de aprendizado, o noviço e suas entidades se tornam cada vez mais sensíveis a camadas de diferenças efetuadas nas práticas que se desenrolam no terreiro.

O que há entre a cabeça e os pés deve ser amolecido para quebrar o jincá. O jincá é uma saudação gestual que mobiliza todo o corpo; um balanço que se irradia por toda a coluna vertebral e se faz notar especialmente nos ombros e no torso. É uma forma de saudação que caracteriza a entidade, orixá, exu ou o caboclo, em todos os momentos, como uma espécie de assinatura em movimento. O jincá marca a saudação de chegada e é também uma reverência à presença física ou enunciada (em cantigas) de 
outras entidades. A realização do jincá em ocasiôes apropriadas atesta se o orixá ou caboclo aprenderam a registrar diferentes situaçóes e se ajustar a elas, quando se movimentam.

O pé de dança pode ser também um exemplo da transformação que a experiência de virar no santo produz, através da articulação entre adepto e entidade. O pé de dança é identificado no filho de santo e nas entidades, seu aprimoramento é fruto de práticas que envolvem cultivo da relação entre eles, mas também depende da dedicação das pessoas iniciadas há mais tempo para ensinar os novatos. Então, o estilo de movimento de cada entidade; seu jeito de realizar o jincá; o barravento que caracteriza sua chegada; e a existência (ou não) do tombo passam pela articulação com os mais velhos, que acontece durante a rotina do terreiro e seus treinos.

No sentido da discussão desenvolvida até aqui, movimento não é sinônimo de colagem de um gesto seguido de outro, conforme aponta Johnstone (2011, p. 204), nem tampouco um reflexo externo (corporal) de uma atividade interna (mental) que o precede. O movimento é como um modo de pensar ligado a dinâmicas qualitativas que se combinam no seu desenrolar. Um modo de pensar que é aprendido, como define Johnstone (2011, p. 242), pela sintonização com, e em resposta, a diferentes situaçóes dinâmicas. Assim, o movimento faz parte do elo entre a vida como é vivida e aqueles que ela enreda. Rodar com caboclo envolve diversas situaçóes práticas que, embora não dependam exatamente de uma escolha de quem as vive, podem adquirir contornos distintos a depender das relaçóes estabelecidas entre rodante e entidade. Os relacionamentos feitos pela entidade dependem, de certa forma, da permanência do adepto no terreiro, da frequência de seu comparecimento na rotina da casa, da intensidade das relaçóes estabelecidas com outras entidades e de como essas relaçóes fazem diferença para quem as vive. Os caboclos aprendem a se conduzir de acordo com o que pede cada ocasião. Ajustam-se, por exemplo, aos modos de pedir bênção na presença de mais velhos e sacerdotes, de reverenciar outras entidades que habitam o local onde se encontram, ou de se retirar caso a presença de uma outra divindade demandar seu afastamento. 
Ocasiôes diversas vividas de maneiras distintas pelos caboclos articulam diferenças nos seus modos de se mover e se portar. Quanto mais articulado for um caboclo - isto é, quanto mais diferenciada for sua maneira de responder às solicitaçóes de pessoas, entidades e situaçôes -, mais possibilidades ele terá de aprimorar seus trejeitos e de se situar nos modos de se mover partilhados pelos demais filhos e entidades da casa. $\mathrm{O}$ modo de cada entidade se movimentar quando ela se faz presente no corpo do rodante também está relacionado à intensidade de sua força e às articulaçóes que ela promove ao virar o filho de santo. A articulação da entidade com a pessoa que roda com ela, expressa também um modo de pensar que é, de certa maneira, distribuído nos nexos que conectam o adepto àquele outro ser que nele se manifesta e ao terreiro que os abriga ${ }^{15}$. Por conseguinte, o adepto que dá santo tem que aprender a lidar com as diferentes solicitações das entidades que o levam a estados que fogem de seu controle. Esse processo produz uma reconfiguração que abre passagem para que a açáo desse outro ser (orixá, caboclo, exu, erê) seja reconhecida e refinada por aqueles que convivem com ele.

Nessa direção, a presença do caboclo passa por um refinamento que envolve o aprimoramento de habilidades corporais. Por exemplo, quando uma entidade pega um filho de santo, a força de sua ação transforma o seu corpo. Essa transformação se faz notar no barravento que caracteriza a chegada da entidade e dá lugar ao seu jeito próprio de se mover e se portar. Esse jeito se expressa de modo enfático depois do barravento, quando o caboclo dá o seu jincá. O jincá, por sua vez, mostra-se de acordo com o tombo do caboclo, que é modulado por aqueles com quem ele convive em

${ }^{15}$ Opipari (2009, p. 235) em seu trabalho sobre o candomblé em São Paulo, discute a relação entre adepto e orixá como um o processo dinâmico que efetiva uma aliança. Segundo ela, quando o adepto "vira" ele desvia daquilo que é. Para a autora, o corpo assume uma atitude particular enquanto essa aliança se efetua performativamente e é descrito como uma superfície de onde emergem formas heterogêneas de existir. A articulação entre adepto e caboclo, como discutida aqui, passa pela modulação performativa corporal de uma atitude particular ao caboclo.

Debates do NER, Porto Alegre, ANo 20, N. 38, P. 243-279, Ago./Dez. 2020 
diferentes situaçôes. E então, gradualmente, cada gesto e postura, o jeito daquele caboclo caminhar, a maneira dele pedir bênção, de segurar uma caneca de bebida - ganha contornos particulares.

Uma outra consequência prática da chegada da entidade é a retirada de sapatos e sandálias dos pés do rodante, pois as entidades devem permanecer descalças, o que indica que a conexão da sola dos pés com o chão é uma condição para a manutenção dessa presença. $\mathrm{O}$ chão concentra e distribui o axé de um terreiro (Rabelo, 2014, p. 261). A terra e as entidades que nela habitam exercem um papel importante na rotina da casa de candomblé e na vida dos seus filhos. No que diz respeito aos caboclos, a implicação dessas entidades com a terra é expressa na afirmação corrente entre os religiosos de que eles são os donos da terra e, por isso, é preciso reverenciá-los periodicamente, a fim de que permitam a realização daquilo que é feito na extensão desta terra que lhes pertence ${ }^{16}$. Além disso, entre os caboclos, o gesto de pedir a bênção a uma divindade africana, a um caboclo mais velho, ou a uma pessoa importante como a mãe de santo da casa, também passa pelo chão. Os caboclos, assim como os filhos de santo, tocam o chão com a cabeça, ou se ajoelham para prestar reverência. $\mathrm{O}$ apoio dos joelhos no chão é algo recorrente para essas entidades ${ }^{17}$. Ajoelhados, eles cantam, posicionam-se diante de pessoas importantes para prestar homenagem (geralmente, com um joelho apoiado no solo e outro dobrado em ângulo reto em frente ao corpo) e eventualmente utilizam o apoio dos joelhos também para sambar.

Uma situação dinâmica que oferece oportunidades para a exposição e ajustes dos modos de se portar e de se mover das entidades é a festa. As festas públicas dedicadas aos caboclos reúnem diversos elementos: sonoridades, substâncias, pessoas e entidades. Nelas, os caboclos podem demonstrar e adquirir destreza ao dançar, de acordo com diferentes andamentos rítmicos

\footnotetext{
${ }^{16}$ Sobre isso, ver: Santos, 1995, p. 59.

17 A posição de joelhos aparece, inclusive, na seguinte salva de caboclo: "Na toalha em que Jesus nasceu/Em cima dela eu me ajoelhei/ Me abençoa, meu pai, me abençoa/ Me abençoa pelo amor de Deus.”.
}

Debates do NER, Porto Alegre, Ano 20, N. 38, P. 243-279, AGo./DeZ. 2020 
dos atabaques. O que depende de uma conexão que mobiliza a relação entre as entidades; entre elas e os ogãs ${ }^{18}$ e equedes ${ }^{19}$ e entre elas e os convidados. Além disso, durante toda a celebração, a manutenção da conexão entre som e movimento é fundamental. Ela ganha importância na relação entre a mão que percute o couro e os pés que pisam o solo, bem como na batida das palmas dos convidados e nas cantigas entoadas pelas entidades ou ogäs que são respondidas em coro. A correlação entre o fluxo rítmico dos atabaques e o desenrolar dinâmico da festa depende diretamente das interaçôes entre os presentes, o que dá relevo aos vínculos estabelecidos entre pessoas e entidades.

Outras relaçôes entram em jogo nessas dinâmicas, como as que decorrem da circulaçáo de substâncias partilhadas e mobilizadas pelos caboclos. É possível pensar em algumas das substâncias como variaçóes da forte relação dessas entidades com diversas plantas e vegetais das quais derivam. $\mathrm{O}$ tabaco está sempre presente em charutos e cigarros. $\mathrm{O}$ gesto de fumar adquire contorno específico quando os caboclos fumam com a brasa dos charutos dentro da boca, invertendo a feição cotidiana do seu manuseio. Diferentes bebidas alcóolicas circulam na festa: a cerveja e a cerveja preta são as mais populares, mas bebidas preparadas com cachaça e ervas, como o aluá e a meladinha também são bastante consumidas. Apesar de cada entidade apresentar predileção por um tipo específico de bebida, o vinho da jurema é um elemento distribuído entre filhos de santo durante as festas, sobretudo nos momentos iniciais em que são realizadas rezas para convocar as entidades, enquanto uma cabaça contendo um preparado de bebida alcoólica com a planta da jurema passa de mão em mão. Todos esses elementos se articulam na festa e parecem abrir caminho para os caboclos sambarem. As descriçóes apresentadas a seguir buscam evidenciar como essas relaçóes adquirem expressão prática na atitude dos caboclos.

18 Religiosos que não viram no santo, mas exercem funçôes importantes nos terreiros, como tocar os atabaques.

${ }^{19}$ Religiosas não rodantes que têm inúmeras responsabilidades na rotina dos terreiros, dentre elas, cuidar das entidades quando viram os filhos de santo.

Debates do NER, Porto Alegre, ANo 20, N. 38, P. 243-279, Ago./Dez. 2020 


\section{A RODA E A FESTA}

Ao tratar da presença dos caboclos nos candomblés baianos, Edison Carneiro (1978) apresenta uma descrição de modos distintos de dançar durante as festas (a formação em roda com movimentos coletivos similares e formação de fileiras com movimentações individuais variadas) que não foram abordados, ou foram pouco especificados nos trabalhos posteriores sobre os caboclos ${ }^{20}$ nesse mesmo contexto. Para a discussão desenvolvida até aqui, a distinção apontada por Carneiro no movimento dançado interessa, ainda que outros autores tenham discorrido mais amplamente sobre o culto ao caboclo no candomblé baiano. A tese do autor de que a entrada de entidades indígenas no candomblé esteja associada a um enfraquecimento ou descaracterização da tradição africana através da mistura das danças dos orixás com danças provenientes de outras tradiçóes, afirmada no trecho a seguir, é menos importante do que a constatação de modos diferentes de dançar que estabelecem dinâmicas muito distintas:

O caráter hierático da dança ritual dos nagôs se modificou no Brasil, primeiro, pela sua aceitaçáo por elementos angolenses e congueses, na Bahia; em segundo lugar, pela imitação do que se supunha ser a dança ritual dos tupis - a cabeça baixa, o corpo curvado para frente, grande e contínua flexão nos joelhos, movimentos principais para fora do círculo - em homenagem às novas divindades caboclas, na Bahia e na Amazônia; e finalmente, nas macumbas, pela tradição anterior das danças semi-religiosas sem estrutura associativa que lhes permitisse fixar um padrão que subordinasse a iniciativa pessoal. [...] Até mesmo o círculo em que se desenvolve a dança no modelo nagô pode ser

${ }^{20}$ Em Samba de Caboclo (1977), Raul Lody apresenta relaçóes do culto ao caboclo com o samba, mas não aborda a distinção entre danças em círculo e em fileiras; Santos (1995, p.107-112) descreve mais detalhadamente as dinâmicas dos ritos aos caboclos, mas não enfatiza essas distinçóes determinadas; Jim Wafer (1991, p. 68-81) apresenta uma tipologia mais elaborada dos sambas de caboclo, mas também não se atém a essas diferentes configuraçóes das danças. Os trabalhos desses autores apresentam mais amplamente o culto ao caboclo e suas características. 
substituído como acontece nas macumbas, pela carga em fileira cerrada em seis, oito ou dez de fundo, em direção aos atabaques (Carneiro, 1978, p. 32).

O ritual nagô aparece como modelo balizador de tradição que apresenta na dança realizada em círculo sua feição sagrada de melhor expressão. De acordo com Carneiro (1978), a aceitação de elementos indígenas, angolenses e congueses, enfraquece a conexão entre dança e liturgia. A presença das entidades caboclas e seu jeito de corpo revelam, para ele, uma diluição da estrutura associativa dos candomblés tradicionais, afastando os rituais, assim modificados do padrão fixado coletivamente. A descaracterização do círculo como forma modelar da dança nagô é dada como exemplo dessa diluição. Ao descrever as danças dos caboclos, Carneiro (1978) destaca a flexão contínua e acentuada nos joelhos, a cabeça baixa e corpo curvado para frente. O autor menciona ainda a falta de uma "estrutura associativa" capaz de frear a iniciativa pessoal, o que de fato parece ocorrer em celebraçóes dedicadas a essas entidades. Ainda que não seja o objetivo do texto discutir origem, modelo ou pureza de cada maneira de dançar, alguns apontamentos mencionados pelo autor podem ser discutidos pensando no modo como distintas composições de movimento são articuladas nas festas dos caboclos.

Numa situação de festa, muitas vezes a assistência responde mais calorosamente com palmas e cantoria quando um caboclo samba com vigor e exibe suas idiossincrasias, do que quando as entidades dançam com movimentos similares realizados em sincronia. Mesmo na partilha de repertórios similares de movimentos, o estilo de cada um deles deriva de uma composição de passos e trejeitos, que não só é específica àquela entidade, como remete às articulaçóes que tornam possível sua presença naquele momento e naquele lugar.

O posicionamento enfileirado, formando um corredor diagonal em direção aos atabaques acontece bastante nas festas de caboclo e dá densidade à dinâmica responsiva estabelecida entre tambor e divindades. Como já mencionado, há uma conexão forte entre os caboclos e os atabaques. Os ogâs são responsáveis por manter um diálogo vivo que acontece durante 
toda a celebração. $\mathrm{O}$ modo como respondem à solicitação dos caboclos afeta as relaçôes entre essas entidades e entre elas e a assistência. Porém, essa configuração não enfraquece a disposição circular que acontece principalmente nos instantes iniciais da celebração e que pode ser retomada ao longo de toda sua duração. $\mathrm{O}$ arranjo concêntrico cria um circuito que muda a ênfase desse diálogo apenas em parte. Nas suas notas sobre a dança dos caboclos, Carneiro (1978) distingue as duas formas de ocupação do espaço com a dança - o círculo e a fileira - e supóe se tratar de formas excludentes. Porém, como veremos nas descriçôes de festas de caboclos mais adiante, a movimentação dessas entidades percorre as diferenças entre essas formas, maximizando as distintas articulaçóes que elas podem promover.

Caboclos são conhecidos como entidades espontâneas e bravias. Ao contrário de orixás e inquíces, que mantêm os olhos fechados ou as pálpebras semicerradas, os caboclos permanecem de olhos abertos, miram e mobilizam as pessoas ao seu redor. São habitantes das matas, exímios conhecedores das folhas, caçadores corajosos ou trabalhadores humildes do sertão e do mar. Conforme discutido por Lody (1977, p. 4-10), cada linha apresenta um estilo próprio de movimentação que, porém, pode diferir a depender da casa. De maneira geral, caboclos de pena apresentam temperamento mais sisudo e desconfiado. Costumam intercalar no seu samba movimentos que remetem a caçadas com arco e flechas ou com lanças. Além disso, agacham-se como quem se esgueira na capoeira, eventualmente se arrastam e rolam pelo chão. Boiadeiros e capangueiros são ousados e brincalhôes. Quando dançam, levam as mãos aos laços e cintos que carregam próximos ao corpo. Seu samba mantém seus joelhos flexionados como em montaria mas, em compensação, têm disposição para realizar saltos e sapateados que ganham altura fora do chão. Marujos sambam se balançando como se estivessem navegando nas ondas do mar ou como se estivessem demasiadamente embriagados para permanecer com o tronco ereto por muito tempo. Podem manejar arpóes e garrafas de bebida, intercalando continências militares às piadas e aos galanteios. O repertório de movimentos dessas entidades é algo amplo, nenhum limite parece ser absoluto para eles, embora demonstrem respeito 
quando outras entidades ou sacerdotes delimitam restriçôes a suas condutas. Suas particularidades dizem respeito às suas histórias. Em comparação com os orixás cujas danças apresentam uma correspondência mais direta com as histórias narradas nos mitos e evocadas nas cantigas que os louvam, os caboclos atravessam possibilidades de movimento que vão além do limite circunscrito pelas narrativas enunciadas nas suas cantigas.

No repertório musical coletivo dos caboclos, apresentado detalhadamente por Chada (2006, p. 110), existem rezas, salvas, sambas e cantigas de sotaque. Cada tipo de canto produz um efeito específico, no instante em que é entoado. As rezas são cantadas nos momentos iniciais das celebrações. Os filhos da casa as entoam sentados em esteiras, banquinhos ou cadeiras (no caso de pais e mães de santo, equedes ou ogãs), diante ou dentro da cabana dos caboclos, um local preparado com folhas onde são colocados os seus objetos pessoais, bebidas e comidas dedicadas as entidades durante as festas. As rezas instauram uma solenidade que convida os caboclos, convocando-os como "mestres que sabem curar", a tomar parte na ocasião. Durante a reza, circula de mão em mão, entre os membros da casa, uma cuia com a bebida ritual preparada com jurema, como já mencionado anteriormente. Tanto a reza, quanto o vinho de jurema fortalecem o caminho que se abre para que as entidades se façam presentes. Rezas também são reservadas aos ritos privados que precedem as festas públicas.

As salvas ${ }^{21}$, por sua vez, que podem ter finalidades variadas, dedicam-se à apresentação da entidade, à convocação de outros caboclos e ao pedido da bênção. Os sambas que se designam a vadiar consistem em melodias curtas e rápidas cujo andamento muda de acordo com o ritmo de quem

${ }^{21}$ As salvas, com finalidades específicas, entre as quais tomar a bênção dos pais e mães de santo e dos ogâs e equedes, são cantigas trazidas pelos Caboclos, na primeira vez em que se manifestam nos filhos e filhas de santo. Compreendem, embora não seja possível identificar o tamanho real, um repertório individual de poucas cantigas que são sempre as primeiras a serem cantadas por eles nas cerimônias e os identificam. Representa o maior grupo de cantigas do repertório dos Caboclos e se multiplicam a cada dia. (Chada, 2006, p. 107).

Debates do NER, Porto Alegre, ANo 20, N. 38, P. 243-279, Ago./Dez. 2020 
dança. Usualmente, eles só são tirados depois das salvas de apresentação das entidades. Sotaques são cantigas entoadas pelos caboclos para mandar recados, tecer críticas, provocar outros caboclos ou outras pessoas. Os sotaques podem trazer comentários sobre acontecimentos internos à rotina do terreiro. Quando isso acontece o teor do recado é mais evidente para aqueles a quem o sotaque é direcionado ${ }^{22}$. O comentário é codificado para a compreensão restrita de quem já sabe do que se trata. A movimentação exibida por cada caboclo varia a depender do que é entoado. O samba é um momento de demonstração das características e das habilidades de cada caboclo, em que o tombo de cada entidade ganha visibilidade. Por exemplo, se o caboclo estiver cantando sua valentia, ele vai demonstrar o vigor e a agilidade de seus gestos e a desenvoltura na utilização de suas ferramentas. Os encantados podem sambar de vários jeitos, a depender do efeito que querem produzir na assistência: podem dançar agachados ou usar o apoio dos joelhos para sambar, o que confere uma destreza especial ao samba. Cada caboclo detém uma certa liberdade em combinar modos de sambar que se moldam à ocasião.

Ademais, as salvas exemplificam um contraste adicional entre caboclos e orixás. Diferente destes, os caboclos têm certa liberdade para compor suas cantigas, assim como tomam iniciativa para receitar e preparar remédios, além de propor e realizar procedimentos como revistas e limpezas. Por conta dessa liberdade, eles muitas vezes surpreendem aqueles com quem convivem. Na medida que cada caboclo tem autonomia para mostrar seu modo de fazer, ele se diferencia dos demais caboclos e aos poucos ensina às pessoas mais próximas a ele a reconhecer e lidar com suas particularidades, tornando-as mais sensíveis à sua presença.

${ }^{22}$ Há uma semelhança entre a composição dos sotaques e o gênero de poesia falada cuja performance é realizada para marcar acontecimentos e enaltecer pessoas célebres. A composição dos orikis, tal como descrita por Barber (2005, p. 175), consiste na amarração de fragmentos autônomos arranjados de maneira que sua coerência depende da presença do sujeito a quem é endereçado.

Debates do NER, Porto Alegre, Ano 20, N. 38, P. 243-279, Ago./Dez. 2020 
Em festas de caboclo, orixás ou inquíces são reverenciados primeiro. Quando adentram o barracão, os filhos da casa se dispóem de forma circular, seguindo uma ordem hierárquica, do pai ou mãe de santo, passando pelos iniciados há mais tempo, seguidos dos mais novos. Com exceção daqueles que tocam atabaques e agogô (ogâs) ou cantam (alabês), que permanecem próximos aos tambores, a disposição dos filhos da casa pode acontecer em dois círculos: um menor, apenas com autoridades religiosas, e outro, com demais filhos de santo e adeptos ainda não iniciados. Cadeiras de metal e madeira estofadas, geralmente posicionadas em local de destaque, recebem convidados importantes de outras casas. $\mathrm{O}$ meio do barracáo se constitui como um centro de convergência do qual irradia o vórtice de movimento provisório, anti-horário, que marca o início do festejo público. Logo no começo da festa, todos que passam pelo centro do barracão fazem uma reverência ao axé, princípio vital que ali se encontra. Essa reverência gestual se diferencia conforme o tempo de feitura do adepto: os mais novos se deitam no chão, os mais velhos levam a mão ao chão e depois à cabeça. Depois de reverenciar o chão e as forças que nele habitam, reverencia-se também a porta de entrada do barracáo com gestos similares. Usualmente, a porta permanece aberta, permitindo que pessoas, entidades e vento passem por ela. Durante a festa, a circulação de pessoas é liberada. Algumas rotas de passagem permanecem movimentadas ao longo de todo o evento.

Os momentos iniciais das celebraçôes costumam passar, necessariamente, pela formação da roda, como aludido anteriormente. $\mathrm{O}$ movimento circular efetua uma concentração e um fortalecimento de forças que circulam entre os presentes. Esse parece ser um momento preciso ao início do evento. Depois de reverenciar orixás ou inquíces com cantigas específicas e danças que se conformam a elas, os caboclos são chamados a comparecer. Os adeptos dizem que a festa "vira pra caboclo". Essa virada implica em mudanças na sonoridade, como no toque dos atabaques (que variam no ritmo e passam a ser percutidos com as mãos), no som dos caxixis tocados por ogás e equedes e no repertório mobilizado de catingas entoadas. A dinâmica circular permanece até a chegada dos primeiros caboclos nos filhos da casa. 
Apesar da roda continuar girando, a tensão desse giro aumenta na medida em que a expectativa pela vinda dos caboclos é maior. A partir de então, o fluxo circular pode ser interrompido e desviado por um barravento a qualquer momento - o que engaja de maneira distinta aqueles que compóem o círculo. A tensão crescente só é dissipada quando os primeiros caboclos são finalmente levados para os cômodos internos da casa para serem vestidos e paramentados.

A diferença entre as entidades fica mais visível aos visitantes uma vez que elas são vestidas: se o caboclo não possui vestimenta própria, a entidade é paramentada com um ojá23 torcido ao redor da cabeça (como uma coroa) e com um pano-da-costa ${ }^{24}$ sobre o torso. Caboclos de água vestem fardamento da marinha, chapéus de palha ou são vestidos com ojá cobrindo a cabeça com um laço atrás da nuca (no caso de entidades femininas relacionadas às águas). Caboclos boiadeiros e capangueiros se paramentam com suas vestes de couro: chapéu, colete e laço. Caboclos de pena reaparecem com seus penachos, lanças e cocares. À volta das entidades, retoma-se a disposição circular que ocupa o barracão, mas com o ar imponente acrescido pelas roupas para suas danças. Em seguida, a roda para de girar para que cada caboclo se coloque diante dos atabaques e inicie a tirar salvas, a começar pelo mais velho ou o anfitrião da festa.

Um caboclo por vez se coloca ajoelhado à frente dos atabaques e tira algumas salvas. Por meio delas, cada qual diz seu nome, reverencia os orixás do filho de santo, saúda a casa e pede bênção da mãe ou pai de santo e das entidades que regem o terreiro. Consecutivamente, as cantigas narram as jornadas percorridas por eles até a casa onde se encontram, louvam a Deus e a Virgem Maria, eventualmente reverenciam a bandeira brasileira e,

${ }^{23}$ Peça de tecido retangular, usado para cobrir a cabeça dos filhos de santo. O tipo de tecido varia conforme a idade do filho de santo, o cargo ou função que ocupa no terreiro, dos mais simples (para adeptos não iniciados) aos mais finos (para pais e mães de santo).

${ }^{24}$ Peça um pouco maior que o ojá, geralmente feito com tecido similar, usada pelas mulheres sobre a região do torso e do ventre.

Debates do NER, Porto Alegre, Ano 20, N. 38, P. 243-279, Ago./Dez. 2020 
finalmente, trazem seu pedido de licença para vadiar e sambar. Enquanto canta, o caboclo pode dar o seu jincá quando a letra da cantiga menciona outra entidade, autoridade ou local. A reverência demonstra que o caboclo reconhece a importância daquilo que saúda, seja para o terreiro em que se encontra, seja para sua própria história, seja ainda para a ocasião em questão. Nesse meio tempo, as demais entidades permanecem mais próximas da assistência, ouvem e respondem às cantigas que podem variar conforme o desenrolar da ocasião. Todas elas fazem questão de que os visitantes respondam em coro a salva tirada, pois é ao som desse coro que seu samba ganha amplitude. Quando o público não responde à altura, apontam a orelha e reclamam em tom de desaprovação. Podem também se queixar com os ogás, mostrar como devem percutir os atabaques corretamente ou entoar sotaques, desafiando-os.

As salvas também podem convocar os participantes da festa a fazer determinados movimentos. Quando um caboclo canta, por exemplo, "um abraço dado/de bom coração/é o mesmo que uma bênção/uma bênção/ uma bênção", a letra dessa salva descreve uma orientação de movimento tanto de quem a enuncia, quanto daqueles com quem a entidade passa a interagir. Nesse instante, a rede de relações dos caboclos é explicitada, pois suas cantigas situam os abraços direcionados àqueles que compóem o círculo mais próximo da entidade.

Só depois de cada um deles se apresentar, o círculo se dispersa ainda mais e a ação do grupo se pulveriza. A partir de então, eles podem sair do barracão para conversar, resolver pequenos assuntos e ir em busca de outros caboclos para convocar. A convocação de outras entidades é feita através de uma proposição que une cantigas específicas e movimentos, como quando um caboclo aponta uma lança na direçáo de alguém, ou cabeceia o ventre de um rodante, ou chuta o ar na direção de uma pessoa, ou provoca uma umbigada, ou, ainda, oferece um abraço. Nesse sentido, o movimento de um caboclo pode propor situaçóes aos outros, configurando-se como proposiçóes em movimento. Essas proposiçóes se associam com cantigas específicas, no caso das salvas de convocação. 
A maneira de cada entidade realizar a convocação varia de acordo com sua linha, a qual pode se dar como um convite alegre para sambar em conjunto, como uma provocação ou como uma brincadeira - conforme situaçôes que serão descritas mais adiante. Caboclos de pena podem dançar como se estivessem caçando um bicho numa mata fechada, agachados, empunhando suas lanças para apontar o alvo de sua chamada ou entregando o objeto a quem querem virar. Uma salva de convocação como "Quem não sabe andar/escorrega no massapê" adverte aos distraídos o risco de tomar um barravento. Outra salva, entoada geralmente por Boiadeiros, diz: " $\mathrm{Na}$ minha boiada está faltando um boi/Está faltando um, está faltando dois". Ao mesmo tempo em que canta, o caboclo de couro pode percorrer todo o barracão; seus pés podem pisotear ágeis o solo como se estivesse cavalgando uma montaria e pode ainda manejar seu laço, como quem se prepara para laçar o boi que fugiu da sua boiada.

Nas celebraçóes, a composição da assistência faz diferença para as relaçóes que serão estabelecidas durante a festa: os ogãa geralmente ficam absorvidos na função de tocar, por vezes fazendo filas para se revezarem nos tambores, no agogô e eventualmente em outros instrumentos. Os filhos de santo que não rodam com caboclos, aqueles que têm cargo dentro do axé (ocupam posiçóes elevadas na hierarquia do terreiro) e as equedes partilham outros afazeres, tais como vestir as entidades, preparar a comida, buscar bebidas, servir os convidados, acender cigarros e charutos, limpar a cerveja caída no chão para evitar que alguém escorregue. Dentre os convidados, existem aqueles que têm vínculos pessoais com a casa - como irmãos de santo de casas irmãs (casas cujos filhos fundadores são feitos na mesma casa matriz), parentes consanguíneos, amigos, conhecidos ou visitantes fortuitos. Todas as relações ficam à mercê de conflitos, zombarias ou louvaçôes fomentadas pelas próprias entidades e podem ganhar ou perder a intensidade através das respostas a suas atitudes. Nesse caso, um ogã pode puxar uma salva de convocação ou um sotaque, reforçando as consequências dessas atitudes, ou pode chamar atenção para outra coisa que possa interessar às entidades, caso queira dispersar esse movimento. Quanto maior a animação e a dedicação 
no canto e nas palmas, mais intensa será a busca dos caboclos pelos seus irmãos. As entidades têm conhecimento daqueles que recebem caboclos ou que podem vir a receber. Surpreendem visitantes leigos ao induzir a chegada de caboclos pela primeira vez. Dessa maneira, a relação estabelecida entre quem samba e quem não samba numa festa pode surtir efeitos em nexos de relaçôes que extrapolam a temporalidade da ocasião.

O que mais eu acho bonito nesse lado espiritual, posso falar como sacerdote é que assim... Desce meio mundo de gente para ver uma festa, eu não conheço, às vezes, não conheço muitos que descem, que vêm para visitar. Mas como é que meu caboclo, no meio de muita gente, sabe que aquela pessoa também tem um caboclo? Então, ele vai mexer naquelas pessoas que também se incorporam, que são irmãos, que são índios, para fazer parte daquela festa naquele momento ali. Entâo, eu acho muito bonito das pessoas chegarem e incorporarem, um caboclo vai chamando outro, o outro chama outro e daí quando pensa que não, pessoas que eu vejo chegar na porta do meu barracão que eu não sei se são ogâs, equedes, se viram no santo, se são pais de santo, $a b i a s^{25}$, não sei de nada. Mas eles sabem de tudo (Pai Roberto em entrevista concedida em junho de 2019).

No trecho acima, Pai Roberto (um pai de santo negro, de meia idade) descreve uma situação em que seu caboclo, Pedra Irá, é o anfitrião da festa. Ele narra que mesmo que desconheça seus visitantes, o seu caboclo percebe a possibilidade de passagem de outras entidades mediadas pela presença dos rodantes em quem podem vir a se manifestar, ainda que a pessoa até então não saiba que roda com caboclo. Pedra Irá é um caboclo de pena, acessível e sério, mas muito receptivo e gentil com seus visitantes e filhos. Pai Roberto conta que a primeira manifestação desse caboclo foi antes de completar seus 16 anos de idade e que era algo muito forte. $\mathrm{Na}$ época, o caboclo se apresentava com comportamento rústico, bruto e bravo, não sabia cantar e não tinha doutrina, provocando medo e fascínio nas pessoas.

${ }^{25}$ Adepto ainda não iniciado.

Debates do NER, Porto Alegre, ano 20, N. 38, P. 243-279, Ago./Dez. 2020 
Passados tempo e convivência com outros caboclos e outras pessoas, ele foi "se lapidando devagarzinho", isto é, aprendeu a tirar salvas e a conversar, e assim, aos poucos, começou a trabalhar, passar banhos etc. Pedra Irá viveu como matéria, como uma pessoa humana. Há muito tempo, ele era um índio Tupi-guarani muito bom para sua aldeia: curava pessoas e tinha êxito como pescador. Mas, depois de um infortúnio que lhe rendeu muito sofrimento e o enfraqueceu, ele acabou falecendo, atingido por uma pedra que rolou do alto de um lajedo. Então Tupã, Deus do seu povo, que o considerava um espírito de luz, concedeu a ele a possibilidade de voltar em terra para ajudar as pessoas. Tanto seu Pedra Irá, quanto o Boiadeiro herdado da mãe de Pai Roberto trabalham no terreiro que recebeu como herança de sua genitora e que está prestes a completar 50 anos.

Ao longo do tempo, a presença de Pedra Irá se transformou, por conta das relaçóes que ele estabeleceu. A entidade aprendeu a conviver com pessoas e a trabalhar. Essa aprendizagem se dá, inclusive, como possibilidade cinética. Um caboclo muito bruto pode não mobilizar os efeitos que um gesto sutil permite, por exemplo. Quanto mais articulaçóes uma entidade faz, mais diferenças ela pode percorrer com suas açóes. Ao passo que aprende a lidar com a variação da sua própria força, o caboclo pode manejar melhor a gama de possibilidades que dela decorre. Dessa forma, os caboclos aprendem a se situar e a compor seu modo de trabalhar e dançar a partir de orientaçôes de ação e de condutas coletivas cultivadas nos relacionamentos que os enreda.

As articulaçóes efetuadas pelos caboclos podem se alastrar fazendo diferença na vida das geraçóes seguintes de quem cruza os seus caminhos. Quando um caboclo deixa de rodar com um filho de santo que faleceu e retoma seu vínculo posteriormente através de outro familiar de gerações seguintes, essas articulaçóes podem se tornar uma condição indispensável para que sua presença na família seja reconhecida como uma continuidade de algo instaurado previamente. A existência dessas entidades herdadas, análogas a orixás "retornados" apresentados por Flaksman (2014, p. 141), liga membros de uma família de épocas diferentes através das pessoas que 
rodam com elas ${ }^{26}$. Este foi o caso do caboclo Lage Mineiro cujos movimentos passo a descrever a seguir.

\section{UM CABOCLO EM MOVIMENTO}

Quem tem, tem/ Quem não tem, quer ter/ Quem tem aparecel Quem não tem, quer aparecer

(Salva de caboclo)

Lage Mineiro é uma entidade herdada. A primeira vez que ele se manifestou na vida de Pai Cley (um jovem pai de santo negro) foi durante sua adolescência. O pai de santo pertence a uma família de pessoas de candomblé. Com exceção de sua mãe, seus outros familiares são iniciados. Desde criança, ele cresceu frequentando as festas na casa de sua avó, que é mãe de santo, e no terreiro em que seu pai foi confirmado ${ }^{27}$ ogã. A primeira manifestação de Lage Mineiro ocorreu quando ele era adolescente, durante a festa de aniversário do caboclo de sua avó:

Ele é filho de um Boiadeiro Menino, foi esse caboclo que trouxe ele a primeira vez para conseguir trazer a manifestação no meu corpo. O Boiadeiro veio com ele espiritualmente e por incrível que pareça a pessoa que recebe esse boiadeiro não estava no momento da festa. Eu passava muito mal de santo, da espiritualidade, eu era jovem, tinha 15 para 16 anos quando ele me pegou a primeira vez. Eu já tinha passado mal num momento da festa, mas ele não pegou logo. Foi na casa de minha avó, me botaram num quartinho que tinha

${ }^{26}$ Embora o texto apresente alguns casos em que as entidades caboclas foram herdadas, isso não é uma regra para as relações tecidas por essas entidades. Pelo contrário, os caboclos são divindades conhecidas por serem dotados de mais autonomia, o que se expressa num modo mais imprevisível de chegar e estabelecer vínculos.

${ }^{27}$ A iniciação de ogâs e equedes acontece de maneira diferente da dos rodantes. Eles são suspensos (o cargo recebido por esses adeptos é anunciado por uma entidade) e em seguida esse cargo é confirmado por procedimentos rituais.

Debates do NER, Porto Alegre, ano 20, N. 38, P. 243-279, Ago./Dez. 2020 
uma janela para o fundo e eu fiquei nessa janela tentando voltar ao normal, foi quando eu vi aquela porta que se arreganhou assim e realmente eu vi aquele homem vestido de couro, apontando para mim. Acho que esse foi o momento da transação porque ele se manifestou em mim a primeira vez. Aí foi quando ele me pegou, trouxe as músicas, salvas, como ele comia, o que ele fazia, quem era ele. E na realidade, ele é um caboclo ancestral da minha família, porque minha tataravó rodou com esse caboclo Lage Mineiro. E eu não conheci ela, porque de nascido tenho 29 anos e de morta ela tem 35 ou 36. [...] A minha avó reconheceu ele através de uma cantiga que ele trouxe, uma salva, que ele canta quando vai embora. Daí minha avó começou a chorar no barracão, na primeira vez que viu ele [...]. Porque minha avó é feita com essa senhora que era minha tataravó. Minha bisa e minha avó fizeram santo com ela que era conhecida como Chica de Mineiro, que era o nome do caboclo, Lage Mineiro. Ela ficou conhecida como Chica de Mineiro e a gente tem ele como se fosse uma herança da família, ele é caboclo de Omolu, que é um outro santo que me rege, eu sou feito de Ossayn, mas meu juntó é Omolu e ele veio nos caminhos, quem trouxe ele como caboclo foi Omolu (Pai Cley em entrevista concedida em setembro de 2018).

Várias dimensões chamam a atenção na história da primeira manifestação de Lage Mineiro no seu filho, Cley. A primeira é que ela aconteceu durante a festa de aniversário do caboclo de sua avó, de maneira que o nexo ativado na festa se estendeu para além daquele evento e fez coincidir o aniversário de Lage Mineiro ao do caboclo da sua avó. A segunda é que o vínculo entre o caboclo de pena e o Boiadeiro Menino se apresentou para o jovem abiã no instante em que ele tentava se reestabelecer após ter passado mal durante a celebração. Embora a pessoa que roda com Boiadeiro Menino não estivesse na festa, a entidade apareceu para o jovem como uma visão, como um mediador da "transação" - a operação que instaurou a presença de Lage Mineiro no pai de santo -, abrindo a porta, trazendo consigo o caboclo de pena que finalmente virou o rodante e inaugurou um relacionamento entre os dois. Essa relação foi reforçada pelo vínculo de filiação entre as entidades - Lage Mineiro é filho de Boiadeiro Menino. A terceira é que

Debates do NER, Porto Alegre, Ano 20, N. 38, P. 243-279, Ago./Dez. 2020 
houve o reconhecimento, pela avó de Cley, de que o caboclo do adolescente era o mesmo que rodava com Chica de Mineiro, de quem foi filha de santo. Como narrado acima, sua avó começou a chorar quando escutou a entidade entoar uma cantiga que era característica de Lage Mineiro desde quando ele ainda rodava na tataravó do pai de santo.

Além disso, é importante atentar para a relaçăo de Lage Mineiro com Omolu. Ele é um caboclo de Omolu. O orixá trouxe o caboclo aos seus caminhos, pois é um dos orixás presentes na composiçấo de divindades que se ocupam do pai de santo. Esse apontamento sugere que um caboclo pode percorrer um caminho de um orixá, ao mesmo tempo em que um orixá pode trazer um caboclo nos caminhos que rege. Isso traz ainda a possibilidade de os caboclos se articularem, ao longo de suas vidas, tanto com seres humanos quanto com orixás, de maneiras distintas. A partir dessa narrativa, é possível imaginar a vida dos caboclos se desdobrando em muitas, atravessando diversas linhas em trajetórias dinâmicas que atravessam geraçôes, temporalidades e espaços diferentes. Ademais, o terreiro de Pai Cley foi adquirido com o fruto do trabalho de Lage Mineiro, apelidado por seus filhos de "menino trabalhador", o que sugere que as articulaçóes das entidades podem ter efeitos tão materiais quanto a aquisiçáo de um terreno, por exemplo. $O$ pai de santo ressalta a gratidáo que nutre pelas pessoas que ajudaram a doutrinar o caboclo que, no início, era muito bravo e, com o tempo, pôde aprimorar seu samba e seu modo de trabalhar. Atualmente, Lage Mineiro é admirado não somente pela beleza e leveza de seu samba, mas também pelo zelo com que toma conta de seu terreiro.

Vi Lage Mineiro dançar em três momentos diferentes: no aniversário do marujo de um pai de santo que é conhecido de Cley, num toque ${ }^{28}$ de caboclo na casa onde Cley foi iniciado e numa comemoração em sua homenagem, na sua própria casa. Em todos esses eventos, sua movimentação leve e atitude alegre envolveram outras pessoas e entidades em interaçōes descontraídas e bem-humoradas. Na primeira ocasiáo, sua chegada se deu no meio da

${ }^{28}$ Algumas cerimônias públicas, aquelas que envolvem música, são chamadas de toque.

Debates do NER, Porto Alegre, ano 20, N. 38, P. 243-279, Ago./Dez. 2020 
festa, em uma roda de caboclos que dançavam, fumavam, bebiam cerveja e demandavam atenção dos ogãs, equedes e demais presentes. Boa parte da celebração tinha transcorrido, passados os momentos iniciais, os mais solenes do rito, os dedicados à reverência dos orixás e inquíces. Visitantes e convidados adensavam o barracão ${ }^{29}$ ao som da viola, das cançóes e dos atabaques. Lage Mineiro se fez, então, presente quando Cley foi convidado para dançar com um caboclo de pena e aceitou o convite. Depois de alguns minutos sambando com o caboclo, o jovem pai de santo tentou sair da roda para voltar a se sentar numa cadeira no canto do barracáo. Porém, o deslocamento foi interrompido por uma leve cabeçada na região do ventre, dada pelo caboclo de pena com quem dançava. O golpe pareceu convocar a chegada da entidade. $\mathrm{O}$ barravento que a antecedeu, virou num giro $\mathrm{e}$ estremeceu em vibraçáo intensa e curta o corpo do rodante, engajando duas ou três equedes que permaneceram próximas para o caso de suceder uma perda abrupta de equilíbrio ou uma queda, o que náo aconteceu.

Quando o caboclo chegou, retirou contas, pulseiras e sapatos do rodante e em seguida foi levado para os quartos internos do terreiro para ser vestido e paramentado. Voltou com uma roupa verde, estampada de folhas, um cinto de palha que prendia algumas cabacinhas e uma vara de bambu. Ao adentrar novamente o barracão, saudou a máe de santo mais velha no local com um salto seguido de um mergulho ondulado que levou sua cabeça para baixo, acompanhada do resto do corpo que parecia planar em direção ao solo, diretamente aos pés da matriarca. Recebidas as bênçãos de duas mães de santo mais velhas sentadas à frente dos tambores, ele se levantou, cantou que vinha de longe e que passara pela mata para chegar até ali. Sua cantiga foi respondida pelos tocadores e pelos demais presentes na festa, enquanto ele brincava com seu samba ágil, marcado por saltos e giros num pé só. Seus rodopios faziam seu tronco desenhar espirais com os ombros, causando ondulaçôes que lembram pequenos redemoinhos de vento. Ele parecia flutuar.

${ }^{29}$ Salão onde acontece a maioria das cerimônias públicas. 
Nessa ocasião, a presença de Lage Mineiro pareceu ser favorecida por uma série de relaçóes. Uma certa conexão pode ser identificada com o caboclo que convidou Cley para sambar, pois foi um golpe desse mesmo caboclo que enfaticamente desencadeou o barravento que precedeu a chegada de Lage Mineiro. A cabeçada abriu uma via para a chegada da entidade. Com a aproximação da cabeça de um filho de santo virado ao umbigo do outro, abriu-se uma passagem para que a presença da entidade se efetuasse. Ao reingressar no barracão depois de vestido, Lage Mineiro náo hesitou, logo se dirigiu aos pés das mães de santo presentes, para as reverenciar, e depois ajoelhou-se diante dos atabaques, saudou a casa e as entidades que a protegem. A ordem da sua ação faz diferença na medida em que indica uma hierarquia de importância. $\mathrm{O}$ encantado demonstrou que conhece o lugar que ocupa como convidado na casa alheia.

A segunda ocasiāo em que vi Lage Mineiro sambar foi durante um toque de caboclo no dia 3 de julho, num terreiro localizado no bairro de Cajazeiras - a casa onde Cley foi iniciado. O pai de santo da casa, um anfitriâo caloroso que demonstrou muita dedicação às entidades e atenção com os preparos da festa, não roda com caboclo, o que não o impediu de acolher e celebrar os encantados de seus filhos. A presença de Lage Mineiro nessa festa foi requisitada pelo convite para sambar junto ao caboclo de um homem altíssimo, forte, muito carismático, de tez retinta, movimentação precisa e gestos amplos. Esse filho da casa estava vestido elegantemente, com bata e calças de tecido africano estampado de azul e cor-de-rosa. Foi esse rodante quem conduziu todo o xirể $\hat{n}^{30}$. Quando chegou seu caboclo, ele foi vestido com um cocar de plumas azuis (anil e marinho) e pretas, entremeadas com penas de pavão, enfeites nos tornozelos com o mesmo padrão (penas em tons de azul, preto e de pavão). A entidade empunhava uma lança de madeira entalhada com padróes geométricos e adornada com mais penas de pavão (que foram distribuídas para algumas pessoas com quem conversou durante

${ }^{30}$ Dança e música do rito público em louvor a orixás ou inquíces. 
a festa). No seu modo de se mover, dois trejeitos eram bastante singulares. $\mathrm{O}$ primeiro era o seu jeito de girar, inclinado diagonalmente, fazendo com que o corpo do filho de santo girasse sempre enviesado entre as linhas horizontais do teto e do chão, direção que desviava o cocar de se chocar no pé direito do barracão. O segundo era uma espécie de preparação, que marcava o início de algumas trajetórias de deslocamento pelo espaço: um pouco antes de caminhar numa determinada direção para saudar uma entidade ou pedir bênção de uma autoridade, ele inclinava o tronco, fazendo um arco com o plexo solar para cima e para trás, acentuado pela dobra dos seus joelhos.

Nessa ocasiáo, foi o abraço desse caboclo que convocou Lage Mineiro. A chegada da entidade produziu, em comparação com a sua chegada na festa descrita anteriormente, menos giros e desestabilizaçôes no equilibro dinâmico no eixo vertical da coluna de Cley. Ainda assim, o caboclo fez vibrar intensamente todo o corpo do rodante, que passou a máo no rosto e na orelha esquerda algumas vezes, como se tentasse se livrar de algo na fronte ou no ouvido. Só depois de alguns instantes, a sua chegada se completou plenamente e ele foi levado ao quarto interno do terreiro para, então, adentrar o barracão trajando vestes brancas e azuis, com suas pequenas cabaças amarradas a cintura, seu chapéu de couro e sua vara de bambu.

Lage Mineiro foi o caboclo que mais cantou e dançou nessa festa. Ele e o caboclo de pena que o convocou viraram alguns dos convidados, chamando a presença das entidades de outros rodantes. A certa altura da festa, um jovem sentado perto da porta de saída do barracáo foi notado pelos dois que sambavam próximos a ele. Os dois encantados passaram a interagir com o rapaz, fazendo uma espécie de jogo, quase como uma brincadeira de sedução que foi se transformando em desafio. Os dois caboclos se deslocavam na direção do jovem para o convidar a sambar, aproximando-se e se afastando dele. Na primeira aproximação, um deles lhe entregou sua lança; depois, o outro lhe colocou o chapéu, a fim de que finalmente aceitasse o convite. Foi então que o jovem se levantou para sambar também, mas não chegou 
a alcançar o centro da roda em que sambavam outros caboclos, pois sua entidade respondeu ao chamado de seus camaradas.

Outro convidado também apresentou uma certa resistência frente à interação dos caboclos. Porém, depois de muitas provocações e convites, seu marujo chegou para sambar com eles. A chegada desse caboclo atiçou o clima geral da comemoração, e os visitantes, até então quase todos sentados, foram obrigados a se levantar para abrir caminho para ele, que a todo momento se movia cambaleante pelo barracão, apoiando-se nas cadeiras com uma mão e segurando uma garrafa de bebida destilada na outra. $\mathrm{O}$ marujo, ao chegar, dobrou o corpo do rodante em dois ângulos de noventa graus. Com os joelhos completamente dobrados e o tronco inclinado para frente, a instabilidade do seu caminhar parecia mais evidente do que o habitual dessas entidades que costumam balançar o corpo, pois, conforme narrado pela entidade, as suas pernas foram quebradas e isso fazia com que elas permanecessem constantemente dobradas. Apesar disso, seu samba meio agachado era bastante firme, numa rearticulação radical dos ângulos e dobras da postura do rodante, tornando sua dança impressionante à primeira vista.

Durante essa ocasião, um dos caboclos presentes, de uma filha de santo alta e jovem, não foi vestido com apetrechos especiais: teve apenas ojá e pano-da-costa amarrados respectivamente na cabeça e no tronco. Com o passar das horas, esse caboclo, muito calado e de gestos contidos, não se apresentou. $\mathrm{O}$ que deu a entender que se tratava de uma entidade novata. Lage Mineiro tomou uma atitude a respeito, pegou o caboclo pela mão, levou-o à frente do pai de santo da casa e cantou uma cantiga pedindo que a liderança e seu orixá abençoassem a entidade que, nesse meio tempo, deitou-se aos pés do anfitrião da festa. Em seguida, levou o novato pela mão à frente dos atabaques, cantando outra cantiga, saudando a casa e apresentando aos convidados a entidade cabocla que permaneceu ajoelhada por alguns instantes. Depois, repetiu a salva cantada antes de tomar a bênção dos convidados e filhos da casa. 
A atitude de Lage Mineiro, ao segurar a mão da entidade mais nova, para que o novato pudesse pegar o jeito, é um exemplo de situação prática de engajamento cinético em que o mais velho mostra o caminho para que o mais novo possa aprender. A aprendizagem também ocorre em situaçóes que envolvem dois ou mais caboclos, em que a intensidade do movimento de um ressoa no do outro, de maneira que um está ao mesmo tempo mostrando ao outro o que está fazendo e se sintonizando com ele para amplificar aquela ação. Uma roda é um exemplo que constitui uma situação de aprendizagem envolvendo diversos caboclos. Quando a roda é composta por caboclos de pena, por exemplo, para sambar juntos, as sutis diferenças que marcam a particularidade de cada caboclo ficam mais evidentes e é possível perceber as semelhanças que aglutinam repertórios de movimentos similares, embora a maneira como são realizados se diferenciem nos trejeitos de cada entidade.

As festas públicas do candomblé são momentos em que as atenções se voltam para aquilo que as entidades podem fazer, para como elas realizam seus feitos e para os movimentos que elas são capazes de executar e de provocar, através da execução de outros. $\mathrm{O}$ modo de cada entidade se colocar em movimento pode reposicionar as dinâmicas qualitativas da festa. Nesse sentido, as habilidades cinéticas e os repertórios gestuais aprendidos por eles com seus mais velhos são acionados. Esse acionamento acontece através das relaçôes que atravessam os membros do terreiro (mas que também existem para além dele), pois a festa é um encontro, uma junção de distintas trajetórias cujos cruzamentos dependem das articulaçôes de cada caboclo. Nesse sentido, o que está em jogo na festa são os modos como a entidade se posiciona, como ela se articula dentro de um repertório coletivo de danças e movimentos e como essa posição reverbera nas relaçóes com as demais entidades e pessoas presentes. Se um caboclo novato não sabe como agir ou não encontra um modo de se posicionar, uma entidade mais velha pode lhe mostrar o caminho, tal como no exemplo da atitude de Lage Mineiro. Conforme percorre esse caminho, o caboclo novo adquire um modo seu de caminhar, de cantar e de sambar. 
A terceira ocasião em que vi Lage Mineiro dançar foi numa celebração em sua homenagem, na sua própria casa. O pai de santo conduziu a primeira parte do rito dedicado aos orixás. Quando a dinâmica virou para caboclo, a sua chegada foi comemorada por todos. Por ter sido o anfitriáo da festa, ele foi o primeiro caboclo a chegar e o último a ir embora. Depois dele, os caboclos dos outros filhos e filhas de santo começaram a chegar. Prontamente, todos foram conduzidos por uma escada, na lateral do barracão, que dava acesso a um quarto restrito do terreiro. Em seguida, cada um se apresentou de maneira singular, tanto no modo de se vestir, quanto no de cantar e dançar.

Uma das entidades chamou atenção por ser a única a permanecer com um fio de conta âmbar ${ }^{31}$ no pescoço e por se apresentar com um ojá amarrado na cabeça, arranjado com um laço na nuca - amarração que a diferenciava das demais entidades. Tratava-se de uma cabocla Iara, uma entidade que habita a água doce. A presença de entidades femininas é algo menos recorrente nos toques e sambas dedicados aos caboclos, por isso elas se fazem notar ao destoarem dos outros encantados. Depois das apresentaçóes de alguns de seus camaradas, Lage Mineiro convidou a cabocla a acompanhá-lo à frente dos tambores. Sua interação com ela se assemelhava ao tratamento dado pelo caboclo às equedes e a outras convidadas que sambaram com ele. A cabocla se portava de maneira distinta: permanecia quase imóvel, agachada em uma posição que lembrava uma pedra de rio, fumando charutos com a brasa voltada para dentro da boca; levantava-se apenas para interagir com uma pessoa ou outra.

Nas três circunstâncias descritas até então, Lage Mineiro se posicionou de maneiras diversas, de acordo com a posição ocupada por ele em cada ocasião. Como convidado na festa do encantado de outra liderança, foi convocado a sambar por outras entidades no calor da celebração. Ao chegar, antes de qualquer coisa, ele reverenciou as autoridades mais velhas no local, saudou as entidades que regem a casa e só então pôde brincar à vontade. Como

${ }^{31}$ Colar ritual que remete à Oxum ou Dandalunda, divindades que são ligadas às águas.

Debates do NER, Porto Alegre, ANo 20, N. 38, P. 243-279, Ago./Dez. 2020 
entidade de um dos filhos de santo do terreiro que promovia a celebração aos caboclos, teve papel importante na condução das dinâmicas da celebração, convocando outras entidades a comparecer à festa e ensinando encantados mais novos a cantarem suas salvas de apresentação, bênção e sambas. Por último, no toque realizado em sua homenagem, no terreiro do pai de santo que roda com ele, no barracão onde se encontra seu assentamento ${ }^{32}$, Lage Mineiro se mostrou com mais liberdade e responsabilidades, uma vez que o desenrolar de cada momento da festa foi ditado por ele e que cada pessoa ou entidade que chegava ao local o reverenciava. As descrições feitas procuram demonstrar como as festas de caboclo agregam diferentes momentos que acionam repertórios de movimentos partilhados, esses movimentos variam conforme a posição ocupada por cada caboclo nas situaçóes dinâmicas vivenciadas e podem acarretar o estabelecimento de vínculos que transbordam a ocorrência temporal das celebraçóes, articulando entidades e pessoas.

\section{CONSIDERAÇÕES FINAIS}

Esse texto buscou abordar a dança dos caboclos no candomblé, em casas localizadas na capital baiana. Ao invés de produzir um inventário dos gestos e movimentos de que essa dança é composta, o trabalho procurou abordá-la pela descrição de situaçóes de sua ocorrência. O movimento das entidades foi discutido através da ênfase em repertórios partilhados no cotidiano dos terreiros e nas dinâmicas que compóem as celebraçóes dedicadas aos caboclos. A maneira peculiar de cada entidade se mover, fruto das relaçóes tecidas com rodantes, membros do terreiro que os abriga, assim como abriga demais entidades, foi tratada através da apresentação de três momentos distintos e suas modulaçóes na dança de Lage Mineiro. Esses dois modos de se acercar da dança abrem a possibilidade de realçá-la como um evento que será tão

$32 \mathrm{O}$ local onde são arranjados os objetos rituais que lhe são próprios e onde é considerada a casa do caboclo no terreiro.

Debates do NER, Porto Alegre, ano 20, N. 38, P. 243-279, Ago./Dez. 2020 
mais rico e diferenciado quanto mais articulados forem seus protagonistas. Evento esse que é capaz de promover novas e criativas articulaçóes.

O jeito com que cada caboclo se apresenta, e como cada qual se coloca na festa, interfere na apresentação e disposição dos demais. Em certo sentido, as dinâmicas da festa são conduzidas pelos ânimos coletivos e pelas relações traçadas por entidades. É a partir do momento em que é dada a licença para sambar que a festa pode adquirir outras dinâmicas, nas quais a composição da assistência passa a ter mais importância. Para que os caboclos e seus gestos façam diferença, é preciso que aqueles que convivem com eles sejam implicados naquilo que eles efetuam. O comentário ou desafio de um caboclo só efetiva uma mudança no transcurso da dinâmica qualitativa da festa se aquele que é alvo de sua ação souber registrar a diferença produzida por ela. Essa articulação não é feita apenas nos momentos públicos pois, para acontecer, necessita da convivência na rotina do candomblé.

Em vista disso, o que é vivido no cotidiano do terreiro é reforçado ou tensionado durante a celebração, diante de quem não participa desse dia a dia. Por isso, o momento das festas coloca à prova disposições apreendidas, conflitos e outras articulações. A distinção qualitativa entre o movimento dançado e não dançado também é enfatizada com a chegada das entidades nas festas públicas. A postura esperada de uma entidade é distinta daquela requerida para um adepto, por exemplo. Os conjuntos de atitudes e movimentos compartilhados como repertórios adquiridos pelas entidades através dos relacionamentos são experimentados durante as cerimônias públicas com outra ênfase, tensionada pela observação dos convidados. $\mathrm{O}$ modo como cada caboclo mobiliza esses repertórios e os recompóem se amplia na convivência com entidades e pessoas que não eram familiares para ele até aquele instante. Por ser um momento em que o terreiro recebe visitantes de fora, outros vínculos inesperados podem ser mobilizados, engajando aproximaçóes para seu cultivo e fortalecimento. A mobilização desse engajamento também depende da habilidade de estabelecer relaçôes com pessoas e entidades diversas, tanto da mesma casa, quanto com visitantes. É através 
da ampliação de articulaçóes possíveis entre as entidades, as pessoas e seus modos de se mobilizar e comover umas às outras que as festas reverberam no futuro de cada entidade, adepto e terreiro.

Por isso, numa festa de caboclo, reconfiguraçóes decorrentes do samba de cada um deles podem conformar zonas situadas de tensão, abrir passagem para a vinda de novas entidades e inaugurar relaçóes que transbordam o momento da festa. À medida em que o samba ganha amplitude e vigor, o movimento que ele produz pode criar rastros, reposicionar direcionamentos, mover tramas que enredam pessoas e entidades, fortalecer articulaçóes antes enfraquecidas e ativar relações com o passado. Os caboclos podem desenhar trajetos imprevistos que avançam ou recuam na temporalidade das relaçóes, bem como podem acionar caminhos que atravessam limites estabelecidos entre passado e futuro: morte e vida, por exemplo. As festas e os sambas são momentos privilegiados para práticas que promovem articulaçóes, porque oferecem situaçôes de adensamento relacional em condiçóes que favorecem o movimento - compreendido como variaçáo qualitativa do presente que se desenrola em direção ao futuro e ao passado - em suas ressonâncias e reverberaçóes.

\section{REFERÊNCIAS}

ANJOS, José Carlos Gomes dos. No território da Linha Cruzada: a cosmopolitica afro-brasileira. Porto Alegre: Editora da UFRGS/ Fundação Cultural Palmares, 2006.

BARBER, Karin. Text and Performance in Africa. Oral Tradition, vol. 20, n. 2, p. 264-277, 2005

CARNEIRO, Edison. Candomblés da Bahia. Rio de Janeiro: Ed. Civilização Brasileira, coleção Retratos do Brasil, volume 106, 1978.

CHADA, Sonia. A música dos Caboclos nos candomblés baianos. Salvador: Fundação Gregório de Mattos/EDUFBA, 2006. 
FLAKSMAN, Clara Mariani. Narrativas, Relaçôes e Emaranhados: Os Enredos do Candomblé no Terreiro do Gantois, Salvador, Bahia. 2014. Tese (Doutorado em Antropologia Social). PPGAS, Museu Nacional, UFRJ, Rio de Janeiro, 2014.

JOHNSTONE, Maxine Sheets. The Primacy of Movement. Philadelphia: Johns Benjamins Publishing, 2011.

LATOUR, Bruno. Como falar do corpo? A dimensão normativa dos estudos sobre a ciência. In: NUNES, João Arriscado; ROQUE, Ricardo (orgs.). Objetos Impuros: Experiências em Estudos sobre a Ciência. Porto: Ediçóes Afrontamento, 2008.

LODY, Raul G. Samba de Caboclo. Cadernos de Folclore. Rio de Janeiro: Ministério da Educação e Cultura, 1977.

LODY, Raul. O povo de santo: Religião, história e cultura dos orixás, voduns, inquices e caboclos. São Paulo: WMF Martins Fontes, 2006.

OPIPARI, Carmen. O Candomblé: Imagens em Movimento São Paulo-Brasil. São Paulo: Editora da Universidade de São Paulo, 2009.

PARÉS, Luis Nicolau. Religiosidades. In: SCHARCZ, Lilia M. GOMES, Flávio (orgs). Dicionário da Escravidão e Liberdade: 50 textos críticos. São Paulo: Companhia das Letras, p. 337-383. 2018.

RABELO, Miriam C. M. Enredos, feituras e modos de cuidado: dimensóes da vida e da convivência no candomblé. Salvador: EDUFBA, 2014.

RABELO, Miriam C.M. Aprender a ver no Candomblé. Horizontes Antropológicos Porto Alegre, ano 21, n. 44, p. 229-251, jul./dez. 2015.

SANTOS, Jocélio Teles dos. Os donos da terra: o caboclo nos candomblés da Bahia. Salvador: Ed. Sarahletras, 1995.

WAFER, Jim. The Taste of Blood: Spirit Possession in Brazilian Candomblé. Philadelphia: University of Pennsylvania Press, 1991. 
Recebido em: 07/08/2020

Aprovado em: 08/10/2020

Debates do NER, Porto Alegre, ano 20, N. 38, P. 243-279, Ago./Dez. 2020 
